\title{
DO IMPROVED GROUNDNUT SEEDS MAKE AFRICAN FARMERS MORE FOOD SECURE? EVIDENCE FROM UGANDA
}

\author{
ANTHONY G. MURRAY* \\ Federal Reserve Bank of Richmond, Charlotte Branch, Charlotte, North Carolina \\ BRADFORD F. MILLS \\ Department of Agricultural and Applied Economics, Virginia Tech, Blacksburg, Virginia \\ GENTI KOSTANDINI \\ Department of Agricultural and Applied Economics, University of Georgia Griffin, Griffin, Georgia
}

\begin{abstract}
Groundnuts are an important crop for Ugandan smallholders because they are high in protein, resupply nutrients to the soil, and are a storable source of wealth once dried. Adoption of virus-resistant seeds that increase yield and reduce yield variance may improve household food security, but the complex relationship is an empirical question. This article considers the effect of improved groundnut seed on smallholder food security in eastern Uganda. Results indicate that adopters have significantly higher household food security after controlling for observed and unobserved household heterogeneity. The food consumption score index increases more than 15 points with improved seed adoption.
\end{abstract}

Keywords. Food security, groundnuts, improved seed adoption, smallholder, Uganda

JEL Classifications: O13, Q12, Q18

\section{Introduction}

Links between agricultural household technology adoption and food security are complex. Agricultural technologies can increase yields or reduce input costs, thereby increasing profits (Feder, Just, and Zilberman, 1985; Sunding and Zilberman, 2001). However, improved technologies may also limit some yield gains in order to stabilize production and profits over time (Kostandini, Mills, and Mykerezi, 2011). Among African smallholders, interactions within the household also play a role in determining how changes in crop productivity

The views expressed in this article are those of the authors and do not necessarily reflect the position of the Federal Reserve Bank of Richmond or the Federal Reserve System. We are grateful to two anonymous reviewers. Research was funded by the Peanut Collaborative Research Support Program, University of Georgia Griffin, grant no. ECG-A-0007-00001.

*Corresponding author: e-mail: anthony.murray@rich.frb.org 
and profits influence food security (Djurfeldt and Djurfeldt, 2013). Key factors include decisions to market or home consume and intrahousehold distribution of production and profits (Doss, 2006b). These complex linkages leave the sign and magnitude of the impact of improved agricultural technologies on household food security as an empirical question.

This article analyzes the impact of improved groundnut seed adoption on smallholder food security in eastern Uganda using a unique household data set on groundnut technologies and food security collected in 2011. Eastern Uganda is one of four defined regions within the country and is bordered by Kenya to its east, Lake Victoria to its south, and the central and northern regions to its west and north, respectively. Within eastern Uganda, the "banana-milletcoffee" system and the "Teso" zones are the two agroecological zones surveyed. In the banana-millet-coffee agroecological zone, rainfall is somewhat variable, and there is a high dependence on annual staple crops, such as maize, millet, and sorghum. The Teso agroecological zone has two rainy seasons, with a dry season between December and March. Crops grown in the Teso system are similar to those in the banana-millet-coffee system. Eastern Ugandan households primarily consume cassava, maize, sweet potatoes, and beans as staple crops (Haggblade and Dewina, 2010). Consumption of these staple crops accounts for almost $75 \%$ of eastern Ugandan smallholders calories. However, groundnuts are one of the primary sources of digestible protein for smallholders (Okello, Biruma, and Deom, 2010).

The impact of improved groundnut seed on food security in the region is of particular interest for a number of reasons. Groundnuts are an especially important crop for Ugandan smallholders, as they are high in protein, can resupply nutrients to the soil, and create storable wealth once dried. Further, groundnuts are grown as a cash crop by household heads and other household members and also for household consumption. This leads to a myriad of pathways for appropriation and distribution of production benefits from the improved seed. Improvements in food security through adoption of the improved seed for a cash crop could stem from higher income when selling the crop at market and lead to an increase in more and nutrient-rich food. Alternatively, adoption of the improved seed might imply that households consume more groundnuts, which would also improve their food security. However, increased yields also raise the possibility that cash crop-oriented foods like groundnuts may divert production efforts from staple food crops and potentially harm household food security (Fafchamps, 1992, 2003). On the other hand, market conditions in eastern Uganda are typical of many rural agricultural areas in Africa: high transportation costs, limited infrastructure, and limited storage options for smallholders after harvest (Kasente et al., 2002). These conditions may limit market responses to improved technology, and improvements in food security may even vary from household to household based on 
consumption-marketing decisions, leaving overall impacts on food security as an empirical question.

In eastern Uganda, the groundnut rosette virus (GRV) is one of the leading causes of diminished groundnut yield (Okello, Biruma, and Deom, 2010). The GRV is unique to Africa even though groundnuts are grown around the world. The virus infects groundnut plants resulting in discoloration of leaves (often yellow tinted or pale green), extreme stunting, and reduced yields. Early infection of groundnuts with GRV can result in total yield loss. Annually, farmers in subSaharan Africa lose more than US\$156 million in groundnut yield because of GRV (Moyo et al., 2007). The virus is transmitted by aphids between plants, and severe outbreaks are sporadic and devastating. Chemical pesticides are available to combat the aphids, but the associated costs prevent most smallholders from using them on their groundnut crops. The Ugandan government has partnered with several nongovernmental organizations to develop GRV-resistant seeds that better protect plants from infection, thereby increasing farmer groundnut yield upon exposure and reducing expected yield variations. The initial release of the resulting improved GRV-resistant (hereafter "improved") groundnut seed in Uganda began in 2002 and is the specific technology examined in this study. ${ }^{1}$

Further, household food insecurity is an important concern in eastern Uganda. In 2008, the United Nations World Food Programme (WFP) conducted a national Comprehensive Food Security and Vulnerability Analysis for Uganda. Six percent of Ugandan households were considered food insecure, and more than $21 \%$ were found vulnerable to food insecurity. In this light, it is ironic that Uganda is sometimes called Africa's "breadbasket" because of its fertile soil and abundant sources of freshwater for farming. Rural households in eastern Uganda are particularly vulnerable to food insecurity. In fact, $43 \%$ of households in the region were food insecure in that they did not consume sufficient calories to maintain an active and healthy life (WFP, 2013).

Agricultural productivity can be substantially improved in Uganda through the adoption of improved agricultural technologies, as yields are consistently found to be higher when smallholders in Africa adopt improved technologies (Karanja, Renkow, and Crawford, 2003; Minten and Barrett, 2008; Moser and Barrett, 2003). However, significant barriers exist in Uganda to the adoption of fertilizer, irrigation, and virus-resistant or high-yield seed (Salami, Kamara, and Brixiova, 2010). Further, unobserved factors that enable households to overcome barriers to adoption may also influence household food security.

1 Several different varieties of improved seed exist, but all except one are GRV-resistant because the rosette virus is the most devastating disease in terms of groundnut yields. Enumerators recorded the specific groundnut seed variety that farmers used, and farmers were then classified as adopters based on a definitive list of improved varieties available within Uganda. 
Thus, self-selection in the adoption decision needs to be accounted for in the estimation of the link between adoption of improved yield and smallholder food security.

Research to date has mainly focused on the ramifications of improved technologies for generalized poverty measures that contain little direct information on household well-being in terms of food consumption. Several recent studies specifically examine improved groundnut seed adoption behavior in Uganda. Kassie, Shiferaw, and Muricho (2011) look at Ugandan groundnut farmers in 74 villages and the effect that improved variety seeds have on household poverty status. The authors find that households adopting improved variety seed are better off in the three basic Foster-Greer-Thorbecke (FGT) poverty indices (incidence, depth, and severity) compared with nonadopters. The income of adopters is also significantly higher than nonadopters. Improved food security is mentioned as a by-product of the increased income from adopting the improved seed, but no explicit analysis of food security is undertaken. Similarly, an ex ante analysis of rural eastern Ugandan groundnut smallholders identifies modest reductions in poverty levels using FGT indices when improved seeds are adopted (Moyo et al., 2007). Kiiza and Pederson (2012) find that access to information services, such as radios, cellular phones, and the Internet, increases adoption of improved groundnut seed in Uganda, but they do not discuss implications for poverty or food security.

Cross-sectional studies, including this one, cannot detect dynamic technological change over time (Doss, 2006a). However, they can provide significant insight on the diffusion of technology at a specific point of time and its impact. A better understanding of the strength of linkages between improved groundnut seed adoption and food security, as well as factors that moderate the strength of the link, are needed to justify agricultural technology investments in terms of benefits to vulnerable rural households. Similarly, establishing a body of evidence for a link between agricultural technology adoption and food security may provide a rationale for differentially targeting traditionally hard-to-reach, food-insecure rural smallholders with improved agricultural technologies. This study examines formal linkages between food security and technology adoption within the broader set of studies that look at technology adoption and its impact on smallholder welfare (e.g., Asfaw et al., 2012; Doss, 2006a, 2006b; Kassie, Shiferaw, and Muricho, 2011).

The remainder of the article is organized as follows: Section 2 outlines the food consumption score (FCS) index employed to measure household food security. Section 3 presents the conceptual framework and specifies the resulting empirical model. Section 4 presents survey summary statistics, and Section 5 provides food security impact estimates from adopting improved seeds. Section 6 simulates the impacts of changes in smallholder adoption behavior, and Section 7 distills policy implications. 


\section{Food Consumption Score Index}

In 1996, the global community agreed on a definition for food security suggested by the WFP as "all people, at all times, have physical and economic access to sufficient, safe and nutritious food to meet their dietary needs and food preferences for an active and healthy life" (FAO, 1996). Research on African food security is ongoing and extensive. Many different measures for the concept exist, including a dietary diversity score index, a coping strategy index, and an FCS index. Each index has positive and negative aspects, but in developing countries, the FCS index has been widely adopted mainly because the WFP has employed it as their staple measure of household food security. The widespread use of the FCS index facilitates comparisons between households on a common metric within and across countries.

The FCS attempts to capture food sufficiency and diversity in a single index. To generate the FCS, households are asked about their food intake over the past 7 days. The enumerator asks about food goods typically consumed and records how often over the past week household members have consumed the goods. As an example, survey participants indicate how many times they ate cassava over the past week and the primary source of acquisition of the good (market, own production, gift, etc.).

The FCS combines different individual foods into eight larger aggregate food categories, such as starches, meats, dairy products, and so forth. Each category is assigned a weight based on its nutritional value. More nutrient- and energy-dense foods, such as meat and dairy, are assigned higher weights, whereas foods with few calories, such as vegetables and fruit, are assigned lower weights. Pulses, which include groundnuts, are weighted slightly more heavily than "staples" because of their nutritional composition, which generally includes more protein than staple grains. When aggregating, the FCS sums the total number of days for each good. When a commodity group contains more than one food type, the number of days each item is consumed is summed up to the censored upper-limit of 7. As an illustration, the meat group contains poultry, red meat, and wild game.

The weights across commodity groups are as follows:

$$
\begin{aligned}
F C S & =(4 \times \text { meat })+(2 \times \text { staples })+(3 \times \text { pulses })+(1 \times \text { vegetables }) \\
& +(1 \times \text { fruit })+(4 \times \text { milk })+(0.5 \times \text { oil })+(0.5 \times \text { sugar }) .
\end{aligned}
$$

After generating the weighted sum, the FCS has a maximum value of 112 (when all categories are consumed 7 days a week). For Uganda, by WFP cutoffs, households with scores less than 28 are food insecure, and households with scores less than 42 are "borderline" food secure, meaning the household is vulnerable to food insecurity. One major limitation of the FCS is the binary nature of its food consumption scoring. The index only measures whether a food group has 
been eaten and the number of days on which it has been eaten. This information omits the quantity of food eaten. Someone who eats 100 grams of meat every day and someone who eats 5 grams would be considered "equivalent" by the FCS index, yet obviously, the one who eats significantly less meat would be comparatively worse off. Although this is a limitation, it is also worth noting that it is difficult to accurately measure consumption across households based on recall, and this can lead to significant errors in estimated calories consumed (de Haen, Klasen, and Qaim, 2011). Therefore, using an index that asks for only simple recall of food group consumption reduces measurement errors. Further, it is the most widely used field measure for assessing household food security.

\section{Conceptual Framework}

The primary focus of this article is on household food security, as measured by the FCS index, and the decision to adopt improved groundnut seed. Obtaining unbiased estimates of this impact is difficult given the fact that the adopters are not randomly assigned but rather are self-selected based on a welfare-enhancing adoption decision. Thus, observable and unobservable attributes that influence both household adoption and household food security need to be controlled for in estimation.

This decision can be modeled under a random utility framework where households are utility maximizing and decide to adopt the improved seed when they receive greater utility from adoption than nonadoption (e.g., Ali and Abdulai, 2010; Asfaw et al., 2012; De Janvry, Dustan, and Sadoulet, 2011). Each household, $i$, faces the decision to adopt, $A^{*}$, given constraints and household characteristics modeled as

$$
A_{i}{ }^{*}=X_{i} \beta_{1}+Z_{i} \gamma+\varepsilon_{i 1}
$$

where $X$ and $Z$ represent vectors of covariates affecting household seed adoption decisions where $\boldsymbol{Z}$ are covariates unique to the adoption decision and $\boldsymbol{\beta}_{1}$ and $\boldsymbol{\gamma}$ represent regression parameters and $\varepsilon_{1}$ is the error term. Latent seed adoption, equation (2), is not directly observed. Instead, observed adoption occurs when latent propensity for adoption is positive $\left(U_{i A}-U_{i N}>0\right)$. Therefore, the observed adoption decision can be expressed in terms of its latent counterpart as

$$
A_{i}=\left\{\begin{array}{ll}
1 & \text { if } A_{i}^{*}>0 \\
0 & \text { if } A_{i}^{*} \leq 0
\end{array} .\right.
$$

Household food security is similarly expected to be affected by household characteristics and the adoption decision.

$$
F C S_{i}=\alpha A_{i}+X_{i} \beta_{2}+\varepsilon_{i 2} .
$$


FCS denotes the household food security index score, $X$ represents a vector of covariates affecting household food security scores, and $A$ indicates an observed binary adoption decision. Similarly to equation (2), $\boldsymbol{\beta}_{2}$ and $\alpha$ represent regression parameter estimates, and $\varepsilon_{2}$ is the error component.

As noted, household food security and adoption of improved groundnut seed are likely to be jointly affected by observed and unobserved attributes within a household, implying that adoption is endogenous because of self-selection.

Estimating both equations jointly through full information maximum likelihood and using instrumental variables in a two-equation treatment effects model with an endogenous binary variable is one method to account for the endogeneity of adoption associated with self-selection based on observable and unobservable characteristics (Wooldridge, 2002). The two error terms, $\varepsilon_{1}$ and $\varepsilon_{2}$, are assumed to be distributed bivariate normal, with a correlation of $\rho$, and the variance of $\varepsilon_{1}$ normalized to 1 . The system of equations is identified by variables in $Z$ that directly affect the seed adoption decision without directly affecting household food security. The resulting likelihood function is

$$
\begin{aligned}
& L=\prod_{A=0} \frac{1}{\sigma_{2}} \phi\left(\frac{F C S-\mathbf{X}^{\prime} \beta}{\sigma_{2}}\right) \Phi\left(\frac{-\left(\mathbf{X}^{\prime} \beta+\mathbf{Z}^{\prime} \gamma\right)-\left(\rho / \sigma_{2}\right)\left(F C S-\mathbf{X}^{\prime} \beta\right)}{\sqrt{1-\rho^{2}}}\right) \\
& \prod_{A=1} \frac{1}{\sigma_{2}} \phi\left(\frac{F C S-\mathbf{X}^{\prime}{ }_{1} \beta-\alpha}{\sigma_{2}}\right) \Phi\left(\frac{\left(\mathbf{X}^{\prime} \beta+\mathbf{Z}^{\prime} \gamma\right)-\left(\rho / \sigma_{2}\right)\left(F C S-\mathbf{X}^{\prime} \beta-\alpha\right)}{\sqrt{1-\rho^{2}}}\right),
\end{aligned}
$$

where $\phi(\cdot)$ represents the normal probability distribution and $\Phi(\cdot)$ represents the normal cumulative distribution functions. Other methods exist to resolve selfselection. For instance, propensity score matching can be employed to account for selection bias on observable variables. However, only a limited set of household variables are available in the data set, suggesting selection based on unobservable variables needs to be accounted for in estimation. On the other hand, a more flexible specification allowing for possible different food security responses of adopting and nonadopting households across all variables could be specified through a switching regression system of equations. The endogenous switching model is in fact a generalization of the two-equation treatment effects model with an endogenous binary variable (Maddala, 1986). In this case, we employ the more parsimonious endogenous treatment effects model, as variables are expected to have the same influence on food security for both adopting and nonadopting households.

\section{Specification and Identification}

The major hypothesis to be tested is that smallholders adopting improved groundnut seed have higher levels of food security. Other household characteristics, including composition and location, are also expected to affect both the FCS index and seed adoption decisions. Variables employed in the 
model specification and expected effects on both equations are discussed in light of previous research. The head of household characteristics age, gender, years of education, and years cultivating groundnuts are included in both the food security and improved seed adoption equations. Older heads of household are expected to have lower adoption propensities. Kiiza and Pederson (2012) observe lower adoption by older heads of household, although Kassie, Shiferaw, and Muricho (2011) find a positive but insignificant effect. Households headed by a male are generally more likely to adopt the improved seed compared with households headed by a female (Moyo et al., 2007). Demeke, Keil, and Zeller (2011) also find that male-headed households in Ethiopia are better able to alleviate food insecure conditions, though the authors find no significant difference in a rudimentary measure of food security. Past studies consistently find that more educated heads of household have higher levels of technology adoption (Demeke, Keil, and Zeller, 2011; Kassie, Shiferaw, and Muricho, 2011). More educated households also have lower levels of poverty and by inference greater food security (Hanjra, Ferede, and Gutta, 2009). More experienced farmers may believe their methods are the "best" based on many years of experience and may be skeptical of new varieties, but the experience may also lead them to see the effect that the rosette virus has on groundnut yield, leading to higher levels of adoption of improved resistant varieties. Therefore, the exact effect on seed adoption of groundnut cultivating experience is left as an empirical question.

Household size may affect both the decision to adopt the improved seed and household food security. Household size has not been found to have a significant impact on adoption for Uganda (Moyo et al., 2007). However, larger households exhibit more food deficit months, something highly correlated with low levels of food security (Kristjanson et al., 2012). Smallholders with larger farms, as measured by total hectares, are expected to have higher levels of adoption (Kassie, Shiferaw, and Muricho, 2011) and also higher levels of food security. Farm size is a proxy for wealth and may be correlated with smallholder ease in purchasing or acquiring the improved seed. Smallholders with more cultivated land are expected to be more food secure because total production is greater, ceteris paribus, and groundnut production improves household food security through both consumption and sales. Finally, the share of land dedicated to groundnut production within a household is also included in the model. Households that primarily focus on groundnut production might have different propensities for adoption, and the impact on food security is likely more pronounced.

Two different distance metrics, distance to market and distance to the main road, are used to determine the rurality of each smallholder. Households residing further from markets are expected to have lower propensities to adopt the improved seed as costs and effort to visit the market are greater. Trips to the market are likely to be less frequent, therefore reducing opportunities to obtain and discuss benefits of the improved seed from other farmers or seed retailers. 
Similarly, households that live farther away from a major road are more isolated and less likely to adopt the improved seed (Kassie, Shiferaw, and Muricho, 2011). Both measures of remoteness are also likely to worsen smallholder food security, as households incur higher costs to selling groundnuts and buying other foods (Alene et al., 2008; Renkow, Hallstrom, and Karanja, 2004). Additionally, village-level fixed effects are included in both equations as proxies for weather, soil quality, and other factors that influence both seed adoption and food security.

Parameter estimates in the FCS equation are identified through exclusion restrictions. Several variables are expected to influence groundnut seed adoption decisions without directly affecting household food security. Specifically, agricultural extension agents provide significant information about new technologies and techniques available to smallholders. An indicator on households receiving a visit from an agricultural extension agent in the past 6 months is included in the adoption propensity equation. Previous studies in Uganda have found that smallholders who receive a visit from an extension agent are more likely to adopt the improved seed (Moyo et al., 2007). A recent study of eastern Uganda observed no statistically significant relationship between farmer field schools and farmer income or agricultural productivity (Davis et al., 2012). Further, an auxiliary regression estimates the effect of an agricultural extension visit on groundnut yield (a measure of productivity) and shows no statistically significant relationship exists within the data. Therefore, the occurrence of a visit should only affect household food security scores through their impacts on improved seed adoption. It should be noted, however, that some studies have found linkages between agricultural extension and productivity in other parts of Africa (e.g., Krishnan and Patnan, 2014; Moser and Barrett, 2003), so this result might be unique to eastern Uganda. It can also be argued that more affluent households may have greater access to extension agents, but the inclusion of a measure of wealth (logged acreage) within both equations controls for this difference. ${ }^{2}$ Finally, an indicator on awareness of the improved groundnut seed is included in the adoption equation. The question asks explicitly about awareness of the improved rosette-resistant seed. Awareness of the improved seed should directly influence the adoption decision, but influence smallholder food security only through the adoption of improved varieties.

Several alternative specifications are also presented to address concerns that visits by an agricultural extension agent influence food security directly instead of only through seed adoption by exploring the robustness of the relationship between the improved seed and food security to the identification strategy employed. An indicator of groundnut loss because of the rosette virus in

2 Auxiliary probit regressions that explore the linkages between household wealth (logged acreage) and extension visits show no statistically significant relationship between the two variables. More information on the strength of the instruments and robustness under alternative specifications is included in the results section (Section 6). 
previous harvests is used as an additional exclusion restriction in one alternative model. Past losses because of rosette likely influence a household's decision to adopt, but arguably would not otherwise directly affect the current food security. Groundnuts are storable over time, which might suggest that loss from the past season would affect current food security. However, $t$-tests for two measures of poverty (income and logged hectares farmed) fail to show any differences between households that lost seed and those that did not. Additionally, households were surveyed in late July at the peak of the currentyear harvest season, making it less likely that stored groundnut from the previous season affected the 7-day recall FCS dietary diversity score. Another alternative specification uses three village-level characteristics that are likely to influence adoption but not food security, instead of employing village-level fixed effects in the adoption equation. The first variable attempts to provide a better measure of social awareness about improved groundnut seed by measuring the share of villagers aware of the improved seed. The second variable measures the villagelevel effect of rosette loss by capturing the number of farmers that claim they lost a portion of their groundnut yield in 2010 as a result of the rosette virus. Because the loss occurred more than a year prior to interview, it would not affect the current FCS score, which is based on a dietary diversity index from food consumption from the current cropping season. The third variable is an indicator for households living within the Teso subregion, a region that is closer to the Serere research station and has faced higher levels of civil unrest in the early 2000s compared with other households within the sample. A final alternative specification uses the nonlinearity of the model to identify the two equations. This is, arguably, the weakest identification strategy but highlights the robustness of the improved groundnut seed adoption-food security relationship.

\section{Data}

Enumerators interviewed households during July and August 2011. The sample focused only on eastern Ugandan groundnut smallholders because of the importance of groundnuts in the region. Forty villages were randomly selected using geographic information system (GIS) software from a list of all known villages within eastern Uganda. ${ }^{3}$ Within each village, the village leader provided a list of all groundnut farmers, and 10 farmers were randomly selected. Enumerators recorded household demographics, crop production, prices, farm characteristics, and food consumption, including questions on the WFP FCS index. Additionally, each farm and groundnut plot was georeferenced using GPS

3 Each village was assigned a number, and then 40 numbers were selected from a random number generator. In a few instances, enumerators had to adjust the selected village because of spelling differences compared with the GIS data. 
Table 1. Summary Statistics

\begin{tabular}{llrr}
\hline \hline Variable Name & N & \multicolumn{1}{c}{ Mean } & Standard Deviation \\
\hline Household food consumption score & 364 & 60.802 & 21.620 \\
Household uses improved seeds $=1$ & 364 & 0.580 & 0.494 \\
Head of household gender (female $=1$ ) & 364 & 0.203 & 0.403 \\
Head of household age & 364 & 46.480 & 13.400 \\
Head of household years of education & 364 & 6.703 & 3.999 \\
Head of household years cultivating & 364 & 12.378 & 11.080 \\
Household family size & 364 & 8.332 & 3.598 \\
Total farmed acreage (logged) & 364 & 1.538 & 0.672 \\
Share of total acreage used for groundnuts & 364 & 0.287 & 0.180 \\
Total household income (U.S. dollars) & 356 & 575.420 & 936.910 \\
Distance to main road (km) & 364 & 3.617 & 4.679 \\
Distance to market (km) & 364 & 6.161 & 6.363 \\
Groundnut loss due to rosette in 2010 $=1$ & 364 & 0.602 & 0.490 \\
Aware of rosette variety seeds $=1$ & 364 & 0.453 & 0.498 \\
Agricultural extension agent visit $\leq 6$ months $=1$ & 364 & 0.236 & 0.425 \\
\hline \hline
\end{tabular}

devices. After excluding incomplete surveys, a total of 368 households from eastern Uganda were included in the sample.

Table 1 provides descriptive statistics for the surveyed households. The mean household FCS index score is significantly above the food insecure (28) and borderline food insecure (42) thresholds, but endangered households still exist. Out of the 368 households surveyed, $20(5.4 \%)$ are considered food insecure with scores below 28 , and an additional 61 households (16.6\%) are considered borderline food insecure with scores between 28 and 42. This means that slightly more than one-fifth $(22 \%)$ of households in the survey live in conditions where the household is either food insecure or in danger of becoming food insecure. These sample statistics are comparable to those from a much larger survey of food security in Uganda where the WFP found $6.3 \%$ and $21.3 \%$ of households were food insecure or borderline food insecure, respectively (McKinney, 2009). A majority (57\%) of sample households have adopted the improved seed. Ideally, data on yields and yield variance would be accurate enough to establish differences between traditional and improved varieties in an on-farm setting. However, it is difficult to disentangle yield difference using the survey data because of significant measurement errors in both field size and quantity produced and in heterogeneity in household skills and exposure to GRV and other shocks.

Poor households are vulnerable to both climatic and price shocks, and food security suffers when households cannot effectively mitigate these shocks. However, eastern Uganda experienced average to above-average rainfall that resulted in favorable harvests in 2011 (U.S. Agency for International Development, 2011). Crop prices showed typical fluctuations during the year, 
with prices highest during the lean season and lowest at peak harvest. ${ }^{4}$ Thus, eastern Ugandan households did not experience any unexpected price shocks that might have influenced the FCS index scores obtained within the sample.

When looking at household head characteristics, few heads of household are female $(20.4 \%)$, and the average age for heads of household is 46 . Heads of household have limited formal schooling (6.67 years on average). The average household head has 12.36 years of experience in groundnut farming, where he or she may have gained informal or institutional knowledge through cultivating fields. Finally, average household size is 8.3 persons, which is slightly higher than in a national survey conducted in 2010. Cultivated acreage, measured in hectares, is logged because of its exceptionally long tail within the distribution and has a log-average equivalent of approximately 4.6 hectares. Land dedicated to groundnut production is nontrivial within the sample households. On average, more than $28 \%$ of land is used for groundnut production within a household. Mean annual household income (in U.S. dollars) is $\$ 572$ but is unreliable as an indicator of wealth as it is self-reported and has a very large variance within the survey.

Proximity to main roads and markets help measure household isolation. Mean distances to roads and markets are 3.6 and $6.2 \mathrm{~km}$, respectively. However, as seen by the standard deviations, there is significant heterogeneity across households in these measures. Finally, only $23.4 \%$ of households indicated interaction with an agricultural extension agent in the 6 months prior to the major groundnut planting season.

\section{Results}

Estimation results from the primary specification are reported in Table 2. Adoption of improved variety groundnut seed significantly improves household food security scores, and the magnitude of improvement is also noteworthy. ${ }^{5}$ By adopting improved groundnut seed, FCSs increase by almost 15 points, or the equivalent of consuming pulses 5 days a week. ${ }^{6}$ One interpretation of the results might suggest that the increase in food security is a construct of the weighting scheme of the FCS index. Under this scenario, adopters would be eating more groundnuts and possibly fewer staples and because of the high FCS weighting on pulses show higher levels of food security. Descriptive statistics,

\footnotetext{
4 Crop price information comes from FEWS NET (i.e., Famine Early Warning Systems Network), but no information on seed prices was collected within the survey itself. Therefore, it is not possible to identify difference in seed prices between improved and traditional seed, nor include any information on household specific prices within the empirical model.

5 Significance, unless otherwise noted, refers to parameter estimates different from zero at $P=0.05$ in a two-tailed $z$-test.

6 The limited sample size of the survey prevents analysis of only those households that are food insecure or those that are borderline food secure.
} 
Table 2. Results of Adopting Improved Seed on Household Food Consumption Score (FCS)

\begin{tabular}{|c|c|c|c|c|}
\hline \multirow[b]{2}{*}{ Variable Name } & \multicolumn{2}{|c|}{ Household FCS } & \multicolumn{2}{|c|}{ Improved Seed Adoption } \\
\hline & Estimate & Standard Error & Estimate & Standard Error \\
\hline $\begin{array}{l}\text { Household uses improved } \\
\text { seeds }=1\end{array}$ & $15.1762^{*}$ & 6.424 & - & - \\
\hline $\begin{array}{l}\text { Head of household gender } \\
\qquad(\text { female }=1)\end{array}$ & 1.8763 & 2.877 & -0.3601 & 0.245 \\
\hline Head of household age & -0.0171 & 0.092 & 0.0030 & 0.008 \\
\hline $\begin{array}{l}\text { Head of household years of } \\
\text { education }\end{array}$ & $1.0183^{* *}$ & 0.289 & -0.0281 & 0.024 \\
\hline $\begin{array}{l}\text { Head of household years } \\
\text { cultivating }\end{array}$ & -0.1155 & 0.118 & -0.0084 & 0.011 \\
\hline Household family size & $-0.5167^{\dagger}$ & 0.305 & -0.0294 & 0.028 \\
\hline $\begin{array}{l}\text { Total farmed hectares } \\
\text { (logged) }\end{array}$ & $9.9977^{* *}$ & 1.894 & 0.1176 & 0.164 \\
\hline $\begin{array}{l}\text { Share of total acreage used } \\
\text { for groundnuts }\end{array}$ & 13.2330 & 7.115 & 0.0778 & 0.670 \\
\hline Distance to main road $(\mathrm{km})$ & 0.0516 & 0.272 & -0.0216 & 0.027 \\
\hline Distance to market (km) & 0.0999 & 0.184 & 0.0067 & 0.016 \\
\hline $\begin{array}{l}\text { Aware of rosette variety } \\
\quad \text { seeds }=1\end{array}$ & - & - & 0.2737 & 0.186 \\
\hline $\begin{array}{l}\text { Agricultural extension agent } \\
\text { visit } \leq 6 \text { months }=1\end{array}$ & - & - & $1.1899^{* *}$ & 0.270 \\
\hline Village-level fixed effects & \multicolumn{2}{|c|}{$\begin{array}{c}28 \text { of } 39 \text { negatively } \\
\text { significant at } P=0.05\end{array}$} & \multicolumn{2}{|c|}{$\begin{array}{c}17 \text { of } 39 \text { positively } \\
\text { significant at } P=0.05\end{array}$} \\
\hline Constant & 57.4335 & 9.436 & -1.3085 & 0.905 \\
\hline$\rho:-0.4988^{*}$ & \multicolumn{2}{|c|}{$\mathrm{N}=364$} & \multicolumn{2}{|c|}{ Log likelihood $=-1,704.7752$} \\
\hline
\end{tabular}

Note: Significance represented at the $10 \%\left(^{\dagger}\right), 5 \%\left(^{*}\right)$, and $1 \%\left({ }^{* *}\right)$ levels.

however, suggest that this is not the case. Staple consumption for adopters and nonadopters is equivalent, and groundnut consumption is actually slightly higher for nonadopters than adopters. Therefore, improvements in food security for improved seed adopters do not appear to stem directly from increased groundnut consumption.

Food security is also influenced by other household factors. Household heads with more formal schooling have significantly higher food security, yet no difference in scores exists from years of cultivation experience. As expected, households farming more acreage also show higher FCS index scores. Additionally, 27 out of 39 village-level fixed effects have a significant negative impact on household food security suggesting that significant crossvillage heterogeneity in food security remains after controlling for household characteristics and other factors. Further, it is worth noting that the base village is outside of the Teso subregion, and 17 out of the 27 significant village-level fixed effects come from the Teso subregion. Although it is not possible to directly observe what is leading to these significant village fixed effects, several patterns 
are worth mentioning. First, agroecological zone differences are not driving the results, as villages from both the banana-millet-coffee and Teso agroecological zones exhibit statistically significant differences from the base village in the banana-millet-coffee agroecological zone. ${ }^{7}$ Other household characteristics are generally similar for households living in villages with statistically significant fixed effects compared with those that are not significant. Experience, as measured by the number of years cultivating, is the only statistically different characteristic, with those households in villages with statistically significant fixed effects averaging approximately 13 years of experience compared with 9 year for households in the other villages.

In terms of adoption, no household characteristics significantly affect household improved seed adoption. Distances to markets and roads also do not have an impact on adoption. Further, awareness of the improved seed does not significantly affect adoption. However, groundnut farmers that had an agricultural extension agent visit them in the 6 months prior to planting are more likely to adopt the improved seed. ${ }^{8}$ A number of village-level fixed effects (17 of 39) are significant in the adoption equation, again highlighting the presence of remaining cross-village heterogeneity. Again, the majority (15) of significant village-level fixed effects come from the Teso subregion, suggesting a higher adoption propensity in the subregion compared with the base village outside of the subregion. Higher adoption of the improved seed in the Teso subregion may stem in part from proximity to the Serere research station, the major groundnut research station where GRV varieties have been tested and released, and from civil unrest that occurred in the early 2000s in the subregion. ${ }^{9}$ The estimate of the error correlation between the adoption equation and food security equation, $\rho$, is negative and significant. This result suggests that after conditioning on observed variables, the remaining unobserved heterogeneity between FCSs and groundnut seed adoption decisions may significantly bias the FCS model parameter estimates if not controlled for in estimation.

Results from alternative specifications show the robustness of the improved seed adoption and improved food security relationship. Tables $3,4(P=0.10)$, and 5 all show statistically significant increased food consumption with adoption

7 Alternative specifications including the agroecological zone continued to show similar results in terms of both statistical significance and magnitude of all variables. Village-level fixed effects remains constant as well.

8 The Cragg-Donald F-statistic for the first-stage instruments is 11.3 , greater than 10 , a commonly accepted standard for strong instruments. The Sargan-Hansen test statistic for overidentification fails to be rejected as well. The Shea's partial $R^{2}$ is 0.07 . Robustness checks when including other instruments such as farmer field school participation ( $F$-statistic: 11.1$)$ and only the agricultural extension visit $(F$-statistic: 22.3) produce parameter estimates similar to those in the primary model. Most importantly, households adopting improved groundnut seed continue to show statistically significant higher levels of food security under these alternative specifications.

9 An alternative specification looks at the impact of distance from the Serere research station on adoption propensities and finds no statistically significant relationship. 
Table 3. Results of Adopting Improved Seed on Household Food Consumption Score (FCS), Alternative Specification 1

\begin{tabular}{|c|c|c|c|c|}
\hline \multirow[b]{2}{*}{ Variable Name } & \multicolumn{2}{|c|}{ Household FCS } & \multicolumn{2}{|c|}{ Improved Seed Adoption } \\
\hline & Estimate & Standard Error & Estimate & Standard Error \\
\hline $\begin{array}{l}\text { Household uses improved } \\
\text { seeds }=1\end{array}$ & $19.6430^{* *}$ & 6.650 & - & - \\
\hline $\begin{array}{l}\text { Head of household gender } \\
\quad(\text { female }=1)\end{array}$ & 2.2144 & 2.954 & -0.3697 & 0.243 \\
\hline Head of household age & -0.0212 & 0.095 & 0.0032 & 0.008 \\
\hline $\begin{array}{l}\text { Head of household years of } \\
\text { education }\end{array}$ & $1.0687^{* *}$ & 0.301 & -0.0259 & 0.024 \\
\hline $\begin{array}{l}\text { Head of household years } \\
\text { cultivating }\end{array}$ & -0.1096 & 0.121 & -0.0085 & 0.011 \\
\hline Household family size & -0.4764 & 0.314 & -0.0309 & 0.027 \\
\hline $\begin{array}{l}\text { Total farmed hectares } \\
\text { (logged) }\end{array}$ & $9.9011^{* *}$ & 1.943 & 0.1171 & 0.162 \\
\hline $\begin{array}{l}\text { Share of total acreage used } \\
\text { for groundnuts }\end{array}$ & $13.1707^{\dagger}$ & 7.315 & 0.0363 & 0.671 \\
\hline Distance to main road $(\mathrm{km})$ & 0.0782 & 0.281 & -0.0211 & 0.028 \\
\hline Distance to market $(\mathrm{km})$ & 0.0848 & 0.189 & 0.0059 & 0.016 \\
\hline $\begin{array}{l}\text { Agricultural extension agent } \\
\text { visit } \leq 6 \text { months }=1\end{array}$ & -2.9498 & 3.182 & $1.2124^{* *}$ & 0.265 \\
\hline $\begin{array}{l}\text { Aware of rosette variety } \\
\quad \text { seeds }=1\end{array}$ & - & - & 0.2712 & 0.180 \\
\hline $\begin{array}{l}\text { Lost groundnuts in } 2010 \\
\text { because of rosette }=1\end{array}$ & - & - & 0.1275 & 0.172 \\
\hline Village-level fixed effects & \multicolumn{2}{|c|}{$\begin{array}{l}28 \text { of } 39 \text { negatively } \\
\text { significant at } P=0.05\end{array}$} & \multicolumn{2}{|c|}{$\begin{array}{c}17 \text { of } 39 \text { negatively } \\
\text { significant at } P=0.05\end{array}$} \\
\hline Constant & 56.9159 & 9.682 & -1.4801 & 0.936 \\
\hline$\rho:-0.5773^{*}$ & \multicolumn{2}{|c|}{$\mathrm{N}=364$} & \multicolumn{2}{|c|}{ Log likelihood $=-1,704.1412$} \\
\hline
\end{tabular}

Note: Significance represented at the $10 \%\left({ }^{\dagger}\right), 5 \%\left({ }^{*}\right)$, and $1 \%\left({ }^{* *}\right)$ levels.

of similar magnitude to that reported in the primary specification. In Table 3, the alternative specification uses past groundnut losses because of the rosette virus and awareness of the improved seed as the exclusion restriction. Table 4 uses village-level exclusion restrictions rather than household characteristics to identify the adoption equation, and Table 5 does not include a specific exclusion restriction. The results of the adoption equation will be further discussed subsequently. Head of household education and households with larger farms continue to show higher levels of food security under these alternative specifications as well. Households that commit larger shares of their land to groundnuts also see higher levels of food security $(P=0.10)$. Additionally, under all three alternative specifications extension visits show no statistically significant relationship with household food security, lending some support 
Table 4. Results of Adopting Improved Seed on Household Food Consumption Score (FCS), Alternative Specification 2

\begin{tabular}{|c|c|c|c|c|}
\hline \multirow[b]{2}{*}{ Variable Name } & \multicolumn{2}{|c|}{ Household FCS } & \multicolumn{2}{|c|}{ Improved Seed Adoption } \\
\hline & Estimate & Standard Error & Estimate & Standard Error \\
\hline $\begin{array}{l}\text { Household uses improved } \\
\quad \text { seeds }=1\end{array}$ & $16.6039^{\dagger}$ & 9.993 & - & - \\
\hline $\begin{array}{l}\text { Head of household gender } \\
\quad(\text { female }=1)\end{array}$ & 2.4099 & 3.042 & $-0.4299^{*}$ & 0.199 \\
\hline Head of household age & -0.0103 & 0.093 & 0.0002 & 0.007 \\
\hline $\begin{array}{l}\text { Head of household years of } \\
\text { education }\end{array}$ & $1.0994^{* *}$ & 0.307 & $-0.0372^{\dagger}$ & 0.021 \\
\hline $\begin{array}{l}\text { Head of household years } \\
\text { cultivating }\end{array}$ & -0.1261 & 0.118 & -0.0012 & 0.009 \\
\hline Household family size & $-0.5363^{\dagger}$ & 0.308 & -0.0193 & 0.023 \\
\hline $\begin{array}{l}\text { Total farmed hectares } \\
\text { (logged) }\end{array}$ & $10.2075^{* *}$ & 1.889 & 0.0531 & 0.132 \\
\hline $\begin{array}{l}\text { Share of total acreage used } \\
\text { for groundnuts }\end{array}$ & $14.6829^{*}$ & 7.124 & -0.3590 & 0.512 \\
\hline Distance to main road $(\mathrm{km})$ & 0.0409 & 0.272 & -0.0031 & 0.022 \\
\hline Distance to market $(\mathrm{km})$ & 0.1002 & 0.184 & 0.0043 & 0.013 \\
\hline $\begin{array}{l}\text { Agricultural extension agent } \\
\text { visit } \leq 6 \text { months }=1\end{array}$ & -1.4272 & 3.402 & $0.8524^{* *}$ & 0.199 \\
\hline $\begin{array}{l}\text { Share of village aware of } \\
\text { improved seed }\end{array}$ & - & - & 0.7200 & 0.510 \\
\hline $\begin{array}{l}\text { Share of village that lost } \\
\text { groundnut in } 2010 \\
\text { because of rosette virus }\end{array}$ & - & - & 0.0116 & 0.409 \\
\hline $\begin{array}{l}\text { Share of village adopters } \\
\text { (other households) }\end{array}$ & - & - & $1.3422^{* *}$ & 0.429 \\
\hline $\begin{array}{l}\text { Household lives in Teso } \\
\text { subregion }=1\end{array}$ & - & - & $0.7223^{* *}$ & 0.268 \\
\hline Village-level fixed effects & \multicolumn{2}{|c|}{$\begin{array}{c}30 \text { of } 39 \text { negatively } \\
\text { significant at } P=0.05\end{array}$} & & - \\
\hline Constant & 55.1669 & 9.797 & -0.9159 & 0.489 \\
\hline$\rho:-0.5436$ & \multicolumn{2}{|c|}{$\mathrm{N}=364$} & \multicolumn{2}{|c|}{ Log likelihood $=-1,735.555$} \\
\hline
\end{tabular}

Note: Significance represented at the $10 \%\left({ }^{\dagger}\right), 5 \%\left({ }^{*}\right)$, and $1 \%\left({ }^{* *}\right)$ levels.

for the variable's exclusion from the food security equation in the primary specification.

The significance of variables varies more in the adoption equation under the alternative specifications compared with the food security equation. Neither awareness of the improved seed nor loss of groundnut yield because of rosette in previous harvests significantly affects household adoption (Table 3). However, households that received an agricultural extension agent still are significantly more likely to adopt the improved seed. The results from the second alternative specification show a statistically significant village-level instrument. Households 
Table 5. Results of Adopting Improved Seed on Household Food Consumption Score (FCS), Alternative Specification 3

\begin{tabular}{|c|c|c|c|c|}
\hline \multirow[b]{2}{*}{ Variable Name } & \multicolumn{2}{|c|}{ Household FCS } & \multicolumn{2}{|c|}{ Improved Seed Adoption } \\
\hline & Estimate & Standard Error & Estimate & Standard Error \\
\hline $\begin{array}{l}\text { Household uses improved } \\
\text { seeds }=1\end{array}$ & $17.9120^{*}$ & 7.385 & & \\
\hline $\begin{array}{l}\text { Head of household gender } \\
\qquad(\text { female }=1)\end{array}$ & 2.0718 & 2.933 & $-0.4050^{\dagger}$ & 0.211 \\
\hline Head of household age & -0.0200 & 0.094 & 0.0027 & 0.007 \\
\hline $\begin{array}{l}\text { Head of household years of } \\
\text { education }\end{array}$ & $1.0568^{* *}$ & 0.298 & -0.0285 & 0.022 \\
\hline $\begin{array}{l}\text { Head of household years } \\
\text { cultivating }\end{array}$ & -0.1114 & 0.120 & -0.0061 & 0.025 \\
\hline Household family size & -0.4914 & 0.311 & -0.0337 & 0.141 \\
\hline $\begin{array}{l}\text { Total farmed hectares } \\
\text { (logged) }\end{array}$ & $9.9573^{* *}$ & 1.923 & 0.1451 & 0.009 \\
\hline $\begin{array}{l}\text { Share of total acreage used } \\
\text { for groundnuts }\end{array}$ & $13.2271^{\dagger}$ & 7.230 & 0.0753 & 0.549 \\
\hline Distance to main road $(\mathrm{km})$ & 0.0749 & 0.278 & -0.0193 & 0.022 \\
\hline Distance to market $(\mathrm{km})$ & 0.0883 & 0.187 & 0.0089 & 0.014 \\
\hline $\begin{array}{l}\text { Agricultural extension agent } \\
\text { visit } \leq 6 \text { months }=1\end{array}$ & -2.4923 & 3.268 & $1.2316^{* *}$ & 0.222 \\
\hline Village-level fixed effects & \multicolumn{2}{|c|}{$\begin{array}{c}28 \text { of } 39 \text { negatively } \\
\text { significant at } P=0.05\end{array}$} & \multicolumn{2}{|c|}{$\begin{array}{l}17 \text { of } 39 \text { negatively } \\
\text { significant at } P=0.05\end{array}$} \\
\hline Constant & 57.2076 & 9.584 & -1.2099 & 0.902 \\
\hline$\rho:-0.5256$ & \multicolumn{2}{|c|}{$\mathrm{N}=364$} & \multicolumn{2}{|c|}{ Log likelihood $=-1,705.5569$} \\
\hline
\end{tabular}

Note: Significance represented at the $10 \%\left({ }^{\dagger}\right), 5 \%\left({ }^{*}\right)$, and $1 \%\left({ }^{* *}\right)$ levels.

in villages with higher shares of improved seed adopters are significantly more likely to adopt the improved seed compared with households in villages with fewer adopters.

As expected, households that live in the Teso subregion show significantly higher adoption propensities compared with those households that do not live in the subregion. The difference in adoption between the subregions again may stem from the fact that the major groundnut research station is located within the Teso subregion, as well as the fact that past conflict within the region may have wiped out traditional seed stock and made the opportunity cost of adoption of the improved seed relatively low. Under this alternative specification, femaleheaded households are now significantly less likely to adopt improved groundnut seed compared with male-headed households, and household heads with more formal education are now less likely $(P=0.10)$ to adopt the improved seed.

In the third alternative specification, no exclusion restriction is included within the adoption equation. As a treatment effects model, it is possible to identify the model solely based on nonlinearity of the probit adoption equation and the 
Table 6. Pagan and Vella (1989) RESET Results

\begin{tabular}{|c|c|c|}
\hline & Adopters & Nonadopters \\
\hline (1) $($ Predicted values $) \times W$ & 0.2934 & 0.4060 \\
\hline (2) $(\text { Predicted values) })^{2} \times W$ & 0.3698 & 0.4759 \\
\hline (3) (Predicted values) $^{3} \times W$ & 0.9699 & 0.4207 \\
\hline (4) $F$ value & 0.6453 & 0.1320 \\
\hline
\end{tabular}

Notes: For adopters, $W$ is equal to $\phi(A) / \Phi(A)$, whereas for nonadopters $W$ equals $-\phi(A) /[1-\Phi(A)]$, where $A$ denotes the values from the auxiliary equation. Rows (1), (2), and (3) report the $P$ value for the null hypothesis that the coefficient is equal to zero. Row (4) contains the significance level of the $\chi^{2}$ value for the null hypothesis that the parameters from rows (1) to (3) are jointly zero. RESET, regression equation specification error test.

assumption of joint normality of the error terms. Although the model is identified without any additional exclusion restriction, this is not a preferred strategy for model identification (Wooldridge, 2002). If the bivariate normal assumption does not hold, the full information maximum likelihood estimation can generate biased and inconsistent results. However, a regression equation specification error test (Table 6) fails to reject the normality assumption in the specification (Pagan and Vella, 1989). In this specification, improved seed adoption continues to improve household food security. In the adoption equation, female-headed households are less $(P=0.10)$ likely to adopt the improved seed relative to maleheaded households, and households receiving an agricultural extension agent visit continue to show higher adoption propensities compared with households that did not receive an extension visit.

Overall, the results across specifications consistently show that households that adopt the improved variety seed have higher levels of food security compared with nonadopting households.

\section{Policy Simulations}

Three simulations based on parameters from the primary empirical model specification are employed to explore implications for household food security and to provide information for potential governmental and nongovernmental agency policy interventions. Several organizations, such as the Ugandan National Agricultural Advisory Services, are already promoting the benefits of improved groundnut seed. The first scenario assumes complete success in distributing improved groundnut seed in eastern Uganda with universal adoption across all smallholders in the sample. Household FCS index scores are recalculated, and with universal improved groundnut seed adoption, mean food security scores increase by 7.5 points or $12.4 \%$ sample-wide (Table 7 ). The simulation on universal adoption does not specify the mechanism for achievement or the associated costs. Universal adoption could come from public subsidies on 
Table 7. Policy Simulations

\begin{tabular}{llc}
\hline \hline Scenarios & $\Delta$ to FCS Index & $\Delta$ as a Percentage \\
\hline All farmers adopt improved groundnut seed & 6.37 & 10.5 \\
Additional year of formal education & 1.02 & 1.67 \\
& \multicolumn{2}{c}{$\Delta$ to Adoption Propensities } \\
\cline { 2 - 3 } All farmers receive agricultural extension agent visit & \multicolumn{2}{c}{0.205} \\
\hline \hline
\end{tabular}

Note: FCS, food consumption score.

the improved seed, informational campaigns about the benefits, or through other incentive structures. A complete analysis of potential policies to approach universal adoption would need to compare all benefits (not just food security increases) with costs.

The second simulation explores increases in head of household education and its effects on improving food security. Household food security increases by less than 1 point on the FCS index when all heads of household have an additional year of education compared with the original mean FCS index score. Although food security scores improve under both of these simulations, there is no discussion of costs. Increasing household education levels is an expensive and long-term project that will yield multiple benefits.

The final simulation looks specifically at the household adoption decision. Agricultural extension agent visits increase the likelihood that smallholders adopt the improved seed. If agricultural extension agent visits are universal, through either an increase in the number of agricultural extension agents or greater efficiency in reaching households with the current number of agents, adoption propensity percentages show double-digit improvements. The increased adoption propensities translate into an almost $5 \%$ increase in average FCS index scores. These are obviously broad and stylized simulations, and appropriate caution should be given to the resulting numbers. However, the simulations do indicate that outreach efforts and resulting improved groundnut seed adoption can materially improve household food security in eastern Uganda.

\section{Conclusions}

This article explores the linkages between smallholder food security and the adoption of improved groundnut seed within eastern Uganda. Use of improved groundnut seed is found to significantly increase food security. As expected, human and physical capital assets also improve food security. On the other hand, household characteristics appear to have limited influence on improved groundnut variety adoption in eastern Uganda. Although agricultural extension agent visits improve adoption, significant village fixed effects suggest that other 
characteristics not observed within this survey, such as social networks and better measures of soil quality, likely drive improved groundnut seed adoption. More research is needed to identify the factors associated with cross-village heterogeneity in adoption.

Observing positive benefits to food security from improved variety adoption has several implications for policy makers. One of the simplest recommendations involves increasing the number of agricultural extension agents. Smallholders that received a visit from an agricultural extension agent are significantly more likely to adopt the improved seed. In situations where it is infeasible for extension agents to reach all households individually, the agents could engage farmers when they are at the local market. Other targeted campaigns to increase awareness on the benefits of improved groundnut seed could be created that focus on highlighting the differences in yield between improved and local varieties, particularly after GRV exposure.

Finally, additional research is needed to understand causal connections between food security and smallholder adoption decisions. The results from this research suggest that in eastern Uganda agricultural technology improvements in a cash-oriented crop like groundnuts can translate into significant improvements in household food security. Further, food security gains appear to come through income pathways rather than increased groundnut consumption. However, more research is needed to understand how this result translates across both commodities and regions.

\section{References}

Alene, A.D., V.M. Manyong, G. Omanya, H.D. Mignouna, M. Bokanga, and G. Odhiambo. "Smallholder Market Participation under Transaction Costs: Maize Supply and Fertilizer Demand in Kenya." Food Policy 33,4(2008):318-28.

Ali, A., and A. Abdulai. "The Adoption of Genetically Modified Cotton and Poverty Reduction in Pakistan." Journal of Agricultural Economics 61,1(2010):175-92.

Asfaw, S., B. Shiferaw, F. Simtowe, and L. Lipper. "Impact of Modern Agricultural Technologies on Smallholder Welfare: Evidence from Tanzania and Ethiopia." Food Policy 37,3(2012):283-95.

Davis, K., E. Nkonya, E. Kato, D.A. Mekonnen, M. Odendo, R. Miiro, and J. Nkuba. "Impact of Farmer Field Schools on Agricultural Productivity and Poverty in East Africa." World Development 40,2(2012):402-13.

de Haen, H., S. Klasen, and M. Qaim. "What Do We Really Know? Metrics for Food Insecurity and Undernutrition." Food Policy 36,6(2011):760-69.

De Janvry, A., A. Dustan, and E. Sadoulet. Recent Advances in Impact Analysis Methods for Ex-Post Impact Assessments of Agricultural Technology: Options for the CGIAR. Rome, Italy: Independent Science and Partnership Council Secretariat, 2011.

Demeke, A.B., A. Keil, and M. Zeller. "Using Panel Data to Estimate the Effect of Rainfall Shocks on Smallholders Food Security and Vulnerability in Rural Ethiopia." Climatic Change 108,1(2011):185-206. 
Djurfeldt, A.A., and G. Djurfeldt. "Structural Transformation and African Smallholders: Drivers of Mobility within and between the Farm and Non-farm Sectors for Eight Countries." Oxford Development Studies 41,3(2013):281-306.

Doss, C.R. "Analyzing Technology Adoption using Microstudies: Limitations, Challenges, and Opportunities for Improvement." Agricultural Economics 34,3(2006a):20719.

. "The Effects of Intrahousehold Property Ownership on Expenditure Patterns in Ghana." Journal of African Economies 15,1(2006b):149-80.

Fafchamps, M. "Cash Crop Production, Food Price Volatility, and Rural Market Integration in the Third World." American Journal of Agricultural Economics 74,1(1992):90-99.

. Rural Poverty, Risk and Development. Cheltenham, UK: Edward Elgar, 2003.

Feder, G., R.E. Just, and D. Zilberman. "Adoption of Agricultural Innovations in Developing Countries: A Survey.” Economic Development and Cultural Change 33,2(1985):25598.

Food and Agriculture Organization of the United Nations (FAO). "Rome Declaration on World Food Security and World Food Summit Plan of Action." World Food Summit November 13-17, 1996. FAO, Rome, Italy. Internet site: http://www.fao.org/WFS/ (Accessed July 7, 2016).

Haggblade, S., and R. Dewina. "Staple Food Prices in Uganda." Paper presented at the COMESA Policy Seminar "Variations in Staple Food Prices: Causes, Consequence, and Policy Options" under the African Agricultural Marketing Project, Maputo, Mozambique, January 25-26, 2010.

Hanjra, M.A., T. Ferede, and D.G. Gutta. "Pathways to Breaking the Poverty Trap in Ethiopia: Investments in Agricultural Water, Education, and Markets.” Agricultural Water Management 96,11(2009):1596-604.

Karanja, D.D., M. Renkow, and E.W. Crawford. "Welfare Effects of Maize Technologies in Marginal and High Potential Regions of Kenya." Agricultural Economics 29,3(2003):331-41.

Kasente, D., M. Lookwood, J. Vivian, and A. Whitehead. "Gender and the Expansion of Nontraditional Agricultural Exports in Uganda." Shifting Burdens: Gender and Agrarian Change under Neoliberalism. S. Razavi, ed. Bloomsfield, CT: Kumarian Press, 2002, pp. 35-66.

Kassie, M., B. Shiferaw, and G. Muricho. "Agricultural Technology, Crop Income, and Poverty Alleviation in Uganda.” World Development 39,10(2011):1784-95.

Kiiza, B., and G. Pederson. "ICT-Based Market Information and Adoption of Agricultural Seed Technologies: Insights from Uganda." Telecommunications Policy 36,4(2012):253-59.

Kostandini, G., B. Mills, and E. Mykerezi. "Ex Ante Evaluation of Drought-Tolerant Varieties in Eastern and Central Africa." Journal of Agricultural Economics 62,1(2011):172-206.

Krishnan, P., and M. Patnam "Neighbors and Extension Agents in Ethiopia: Who Matters More for Technology Adoption?" American Journal of Agricultural Economics 96,1(2014):308-27.

Kristjanson, P., H. Neufeldt, A. Gassner, J. Mango, F.B. Kyazze, S. Desta, G. Sayula, et al. “Are Food Insecure Smallholder Households Making Changes in Their Farming Practices? Evidence from East Africa." Food Security 4,3(2012):381-97.

Maddala, G.S. Limited-Dependent and Qualitative Variables in Econometrics. New York: Cambridge University Press, 1986.

McKinney, P. Comprehensive Food Security and Vulnerability Analysis: Uganda. Rome, Italy: United Nations World Food Programme, 2009. 
Minten, B., and C.B. Barrett. "Agricultural Technology, Productivity, and Poverty in Madagascar.” World Development 36,5(2008):797-822.

Moser, C.M., and C.B. Barrett. "The Disappointing Adoption Dynamics of a Yield-Increasing, Low External-Input Technology: The Case of SRI in Madagascar.” Agricultural Systems 76,3(2003):1085-100.

Moyo, S., G.W. Norton, J. Alwang, I. Rhinehart, and C.M. Deom. "Peanut Research and Poverty Reduction: Impacts of Variety Improvements to Control Peanut Viruses in Uganda." American Journal of Agricultural Economics 89,2(2007):448-60.

Okello, D.K., M. Biruma, and C.M. Deom. "Overview of Groundnuts Research in Uganda: Past, Present and Future.” African Journal of Biotechnology 9,39(2010):6448-59.

Pagan, A., and F. Vella. "Diagnostic Tests for Models Based on Individual Data: A Survey." Journal of Applied Econometrics 4,S1(1989):S29-S59.

Renkow, M., D.G. Hallstrom, and D.D. Karanja. "Rural Infrastructure, Transactions Costs and Market Participation in Kenya." Journal of Development Economics 73,1(2004):349-67.

Salami, A., A.B. Kamara, and Z. Brixiova. "Smallholder Agriculture in East Africa: Trends, Constraints and Opportunities." Working Paper Series No. 105, Tunis, Tunisia: African Development Bank, 2010.

Sunding, D., and D. Zilberman. "The Agricultural Innovation Process: Research and Technology Adoption in a Changing Agricultural Sector." Handbook of Agricultural Economics 1A(2001):207-61.

United Nations World Food Programme (WFP). Comprehensive Food Security and Vulnerability Analysis: Uganda. Rome, Italy: WFP, 2013.

U.S. Agency for International Development (USAID). Famine Early Warning Systems Network (FEWS NET) Uganda Food Security Outlook Update. Washington, DC: USAID, Technical Report, 2011.

Wooldridge, J.M. Econometric Analysis of Cross Section and Panel Data. Cambridge, MA: MIT Press, 2002. 